The International Journal Of Engineering And Science (IJES)

|| Volume || 6 || Issue || 1 || Pages || PP 60-65 || 2017 ||

ISSN (e): $2319-1813 \operatorname{ISSN}(\mathrm{p}): 2319-1805$

THE IJES

\title{
Comparison of Discoloration with Sensory and Chemical Qualities of Gray Mullet (Mugilcephalus L. 1758) Held at Room Temperature
}

\author{
İrfan Keskin ${ }^{1}$, Bayram Köstekli ${ }^{2}$, Asiye D. Eyuboglu ${ }^{3}$, M. Emin Erdem ${ }^{4}$ \\ ${ }^{I}$ Faculty of Fisheries, Sinop University Sinop, Turkey \\ ${ }^{2}$ Faculty of Fisheries, Sinop University Sinop, Turkey \\ ${ }^{3}$ Faculty of Fisheries, Sinop University Sinop, Turkey \\ ${ }^{4}$ Faculty of Fisheries, Sinop University Sinop, Turkey
}

\begin{abstract}
In this study, the changes in biochemical, sensory properties and discolorationof gray mullet, kept at room temperature, were investigated. For this purpose, gray mullets, kept at room condition for 36 hours, were analyzedhourly with sensory and color analysis from five different parts of fish and TVB- $N$ analysis were carried out every four hours and was compared with color change of these parts.According to the results of these analysis, color analysis values were compared with sensory and chemical analysis values changes hourly. While the same fish sample was used for sensory and color analysis. For TVB-N analysiswasuseddifferentfishsample.According to the results of chemical analysis, While the TVB- $N$ value were found as $16.92 \pm 0.12 \mathrm{mg} / 100 \mathrm{~g}$ at the beginning of the experiment, it was were found as $35.93 \pm 0.16 \mathrm{mg} / 100 \mathrm{~g}$ at the end of $36^{\text {th }}$ hours, exceeding the consumable limit value.As forresult of the color analysis, the color analysis values, measured from eye of gray mullet were found asL *: 47.06, $a^{*}: 5.54, b^{*}: 6.58$ and $L^{*}: 55.99, a^{*}: 2,73$, $b^{*}: 8,23$ at the beginning and end of the experiment, respectively.The values measured from the gills at the beginning and end of the experiment were determined as $L^{*}: 25,63, a^{*}: 19,91, b^{*}: 1,21$ and $L^{*}: 32,16, a^{*}: 10,53$, $b^{*}: 3,14$, respectively.In the sensory analysis performed by the panelists, the mullet was evaluated on the basis of color, smell and overall appearance.Having taken high-score, gray mullets at the beginning of trial was determined as inconsumable by taking low scores at the end of $12^{\text {th }}$ hours. This study is a model study. Therefore,more comprehensive research can be done by establishing experiments with different fish species and in different environments. Literature may gain new information comparingly color analysis with quality analysis.
\end{abstract}

Keywords: Chemical quality, Gray mullet, Color analysis, Room condition, Shelf life.

Date of Submission: 04 January $2017 \quad$ Date of Accepted: 26 January 2017

\section{INTRODUCTION}

There are a number of factors that affect the quality of fish. In the course of periods from hunting to transporting to consumers, factors such as interruption of cold chain, storage yard, hygiene, packing and physical impacts considerably affect the quality.

Fishes have an easily degradable structure due to limited number connective tissues and high water content in their organisms. As a consequence they have to held under preservation after prey. Also, due tothey are rich in respect to unsaturated fatty acids, these fatty acids are eventually oxidized in the presence of oxygen, and affect the quality of fishes afterwards they give rise to undesirable changes such as altering taste, tissue structure, release of gases and discoloration [1].

Fresh fish has a bright skin, not collepse and not matte eyes, firm flesh, red gills and smells like a sea. The flora in intestines of fish and the slick layers of the fish surface is caused by the breakdown of the fish. In consequence of these changes occur in the structure of fish appears nitrogenous compound and takes place products, emitting unwanted malodor to surrounding, such as the amine component, trimethylamine, ammonia, sulfur compounds, mercaptans and indole[2].

The most noticeable criterion by the consumer when purchasing aquatic products is usually the product's color. Products looking bright or eye-pleasing attract more attention of consumer. This visual evaluation may be misleading due to external factors such as ambient light and fatigue. Color measuring devices are available for accurate detection. Thus, color measurement devices may offer more reliable results for the color quality of products. Colors can be practically measured by means of CIE(Commissioninternationale de 1'éclairage) a standard method. Color of a food is expressed with $L^{*}, a^{*}$ and $b^{*}$ parameters [3]. L* value indicates the 
changes in luminosity of colors. As the Values approaches near 100, correspond to maximum luminosity and as the values approaches near 0 , correspond to dark (black) colors. The other values and corresponding colors are as follows: $a^{*}(+)-r e d, a^{*}(-)$ green, $b^{*}(+)$ yellow and $b^{*}(-)$ blue[4].

This is a model study. This study was carried out to determine the relationship between the shelf life and the discoloration of the mullet stored in room conditions. It is aimed to making a sensory, chemical and color analyzes of mullet fish, kept at room conditions for 36 hours, at certain hours compare color change with other quality analyzes.

\section{MATERIAL AND METHODS}

15 Gray mullet (Mugilcephalus L. 1758)obtained from the fish market in Sinop province were brought to the laboratory, storing under cold conditions; and were kept at room temperature. In order to determine both the changes in its qualityand its shelf life at room temperature; sensory and color analyzes were performed every hour, and TVB-N analysis were carried out every 4 hours in the course of 36 hours. While a different fish was used for each TVB-N analysis, the same fish was analyzed for color and sensory analyzes.TVB-N values were carried out according to the Lücke-Geidel method [5] and the results were given as $\mathrm{mg} / 100 \mathrm{~g}[6]$.

The Color analysis was done with Minolta CR- 400 Chronometer according to the CIE scale(Commission internationale de 1'éclairage). The values were given as $\mathrm{L}^{*} \mathrm{a}^{*} \mathrm{~b}^{*}$. Measurements were made by calibrating the color device from the calibration table to measure the color of the five parts of the fish, including the eye, gill, skin, flesh and ventral surface. White plate of the device was used for calibration [7].

For sensory analysis of gray mullets were selected 5 experienced panelists.In the sensory analysis performed by panelists on an hourly basis and they were evaluated by giving a score between 0 and 10 in terms of color, smell and overall appreciation (1-2: not consumable 3-4: bad, 5-6: consumable, 7-8: good, 9-10: excellent). The sensory analysis is modified fromÜnlüsayıı and Erdilal [8]statisticalanalyseswereperformedbyMinitab 17 statisticalsoftware(MinitabInc. StateColloge, PA). [9]

\section{RESULTS}

On the purpose of determine the chemical quality of the gray mullet whichkept in room temperature, TVB-N analysis was performed every 4 hours.According to the results of chemical analysis, TVB-N value, which was $16.92 \pm 0,12 \mathrm{mg} / 100 \mathrm{~g}$ at the beginning of the experiment, was found as $35.93 \pm 0,16 \mathrm{mg} / 100 \mathrm{~g}$ subsequent to 36 hours, exceeding the consumable limit value $(\mathrm{p}<0,05)$. Thereresultsareshown in Table 3.1 .

Table3.1.Theresults of TVB-N analysis

\begin{tabular}{|l|l|}
\hline Hour & TVB-N $(\mathbf{m g} / \mathbf{1 0 0 g})$ \\
\hline Begining of experiment & $16,92 \pm 0,12^{\mathrm{h}}$ \\
\hline $\mathbf{4}^{\text {th }}$ & $19,92 \pm 0,38^{\mathrm{fg}}$ \\
\hline $\mathbf{8}^{\text {th }}$ & $18,70 \pm 0,25^{\mathrm{fgh}}$ \\
\hline $\mathbf{1 2}^{\text {th }}$ & $17,85 \pm 0,17^{\text {gh }}$ \\
\hline $\mathbf{1 6}^{\text {th }}$ & $21,31 \pm 0,92^{\text {ef }}$ \\
\hline $\mathbf{2 0}^{\text {th }}$ & $23,35 \pm 0,60^{\mathrm{de}}$ \\
\hline $\mathbf{2 4}^{\text {th }}$ & $25,26 \pm 1,02^{\mathrm{d}}$ \\
\hline $\mathbf{2 8}^{\text {th }}$ & $28,33 \pm 0,60^{\mathrm{c}}$ \\
\hline $\mathbf{3 2}^{\text {th }}$ & $31,69 \pm 0,46^{\mathrm{b}}$ \\
\hline $\mathbf{3 6}^{\text {th }}$ & $35,93 \pm 0,16^{\mathrm{a}}$ \\
\hline
\end{tabular}

Values are shown as mean \pm standard error $\mathrm{a}, \mathrm{b}, \ldots . \mathrm{e} \downarrow$ : Within the column, values with different letters are significantly different $(\mathrm{P}<0.05)$.

As a result of keeping of the gray mullet at room temperature, images of takes place deterioration phasesingeneral appearance at the beginning, the $12^{\text {th }}$ and the $36^{\text {th }}$ hoursof the experimentwere shown in Fig. 3.1, Fig. 3.2, and Fig. 3.3 respectively.

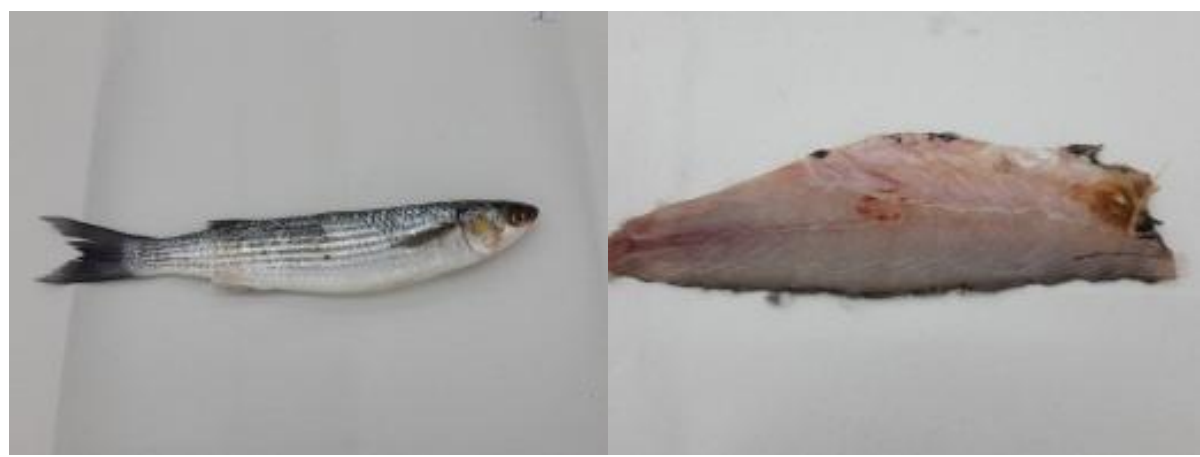


Figure3.1.General appearanceof graymullet at thebeginning of experiment

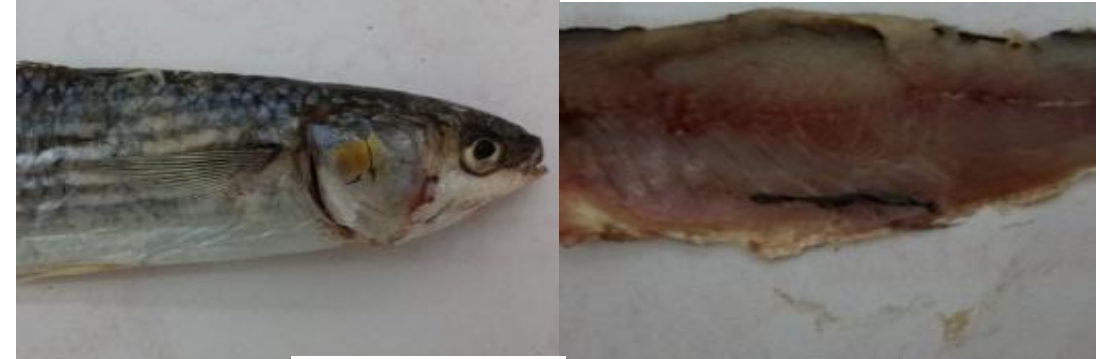

Figure3.2.General appearanceof Graymullet at the $12^{\text {th }}$ hour

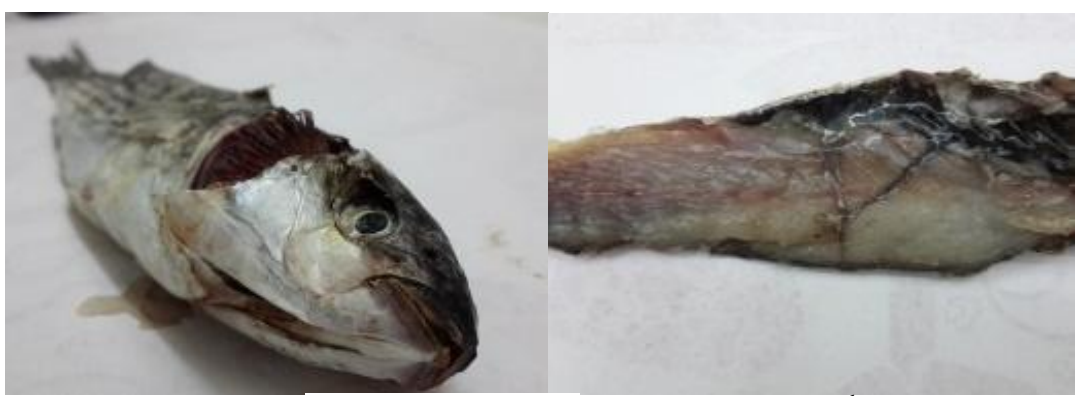

Figure3.3.General appearanceofGraymullet at $36^{\text {th }}$ hour

During the experiment by performing color analysis on the gray mullet, the color differences was computationally expressed.Throughout the experiment, measurements were made every hour from the 5 different parts of the fish, including the ventral surface, head, gill, muscle and skin.The results of color analysis are shown in Table 3.2.In general, it is necessary to evaluate the changes in fisheries as blackness-whiteness (L).At the beginning of the experiment, the $\mathrm{L}$ value was decrease from 50.66 to 36.96 at the end of the experiment, that is, the loss of quality was began and the meat color was stared to blacken.Redness of gills was the most obvious freshness criterion. The $\mathrm{a}^{*}$ value indicating redness was determined at the beginning and end of the experiment as; 19.91 and 10.53 respectively. According to color and TVB-N analysis results when the a $*$ value falls below 11 in the gills, It is possible to express that the gray mullet cannot be consumed. At the same time, the $b^{*}$ value in the Table 3.2 does not seem to give a clearly result in terms of quality.

Table3.2. Thereresultsof coloranalysis (L:0 black, L:100 white, $\mathrm{a}^{*}(+)$ red, $\mathrm{a}^{*}(-)$ green, $\mathrm{b}^{*}(+)$ yellow, $\mathrm{b}^{*}(-)$ blue) 
Comparison Of Discolouration With Sensory And Chemical Qualities Of Gray Mullet...

\begin{tabular}{|c|c|c|c|c|c|c|c|c|c|c|c|c|c|c|c|}
\hline & Eye & & & Gill & & & FishM & & & Ventr: & Surfac & & Skin & & \\
\hline Hour & $\mathrm{L}^{*}$ & $\mathrm{a}^{*}$ & $b^{*}$ & $L^{*}$ & $\mathrm{a}^{*}$ & $\mathbf{b}^{*}$ & $\mathrm{~L}^{*}$ & $a^{*}$ & $\mathbf{b}^{*}$ & $L^{*}$ & $a^{*}$ & $\mathbf{b}^{*}$ & $\mathrm{~L}^{*}$ & $a^{*}$ & $b^{*}$ \\
\hline Begining & 47,06 & 5,54 & 6,58 & 25,63 & 19,91 & 1,21 & 50,66 & 2,04 & $-2,79$ & 99,46 & $-0,50$ & 7,03 & 88,48 & 0,05 & 0,87 \\
\hline $1^{\text {st }}$ & 49,19 & 1,44 & 2,22 & 24,27 & 19,09 & 0,56 & 45,09 & 2,83 & $-2,12$ & 97,58 & $-1,51$ & 6,19 & 81,30 & 0,77 & $-2,76$ \\
\hline $2^{\text {ad }}$ & 45,01 & 2,21 & 5,30 & 28,27 & 20,95 & 0,09 & 42,78 & 1,77 & $-3,21$ & 97,31 & $-0,78$ & 6,79 & 82,85 & 0,46 & 2,70 \\
\hline $3^{\text {rd }}$ & 41,46 & 3,17 & 3,99 & 23,46 & 19,15 & 1,23 & 43,00 & 2,26 & $-3,24$ & 97,16 & $-0,43$ & 4,85 & 83,51 & 0,41 & $-1,75$ \\
\hline $4^{\text {th }}$ & 49,28 & 1,65 & 2,51 & 29,36 & 19,15 & 0,64 & 43,71 & 2,78 & $-3,73$ & 98,43 & $-1,74$ & 6,28 & 84,69 & $-0,61$ & 1,01 \\
\hline $5^{\text {th }}$ & 51,69 & 1,82 & 4,14 & 31,45 & 13,52 & 2,01 & 40,19 & 5,15 & $-2,05$ & 98,08 & $-1,82$ & 5,33 & 78,07 & $-0,29$ & 1,98 \\
\hline $6^{\text {th }}$ & 50,73 & 2,66 & 3,20 & 35,21 & 18,08 & 1,58 & 43,59 & 3,76 & $-2,84$ & 99,01 & $-0,99$ & 3,96 & 80,29 & 0,13 & $-1,03$ \\
\hline $7^{\text {th }}$ & 48,78 & 2,25 & 2,21 & 35,22 & 13,08 & 5,08 & 44,19 & 3,65 & $-1,58$ & 95,45 & $-0,51$ & 3,94 & 68,64 & 0,28 & $-1,37$ \\
\hline $8^{\text {th }}$ & 42,87 & 2,03 & 2,97 & 34,67 & 13,61 & 6,55 & 42,55 & 5,13 & $-0,21$ & 94,78 & $-0,56$ & 3,68 & 69,45 & 0,32 & $-0,52$ \\
\hline $9^{\text {th }}$ & 49,22 & 2,19 & 4,77 & 27,15 & 18,65 & 1,11 & 41,17 & 1,18 & $-1,99$ & 99,79 & $-1,60$ & 7,16 & 76,04 & $-0,18$ & $-0,83$ \\
\hline $10^{\text {th }}$ & 42,14 & 2,06 & 3,72 & 27,35 & 12,80 & 3,39 & 44,73 & 1,55 & $-0,34$ & 95,59 & $-0,63$ & 6,20 & 65,73 & $-0,34$ & $-1,69$ \\
\hline $11^{\text {th }}$ & 46,42 & 2,16 & 3,67 & 27,46 & 12,54 & 3,60 & 42,26 & 2,12 & $-0,67$ & 95,51 & $-1,14$ & 5,17 & 64,61 & $-0,38$ & $-1,55$ \\
\hline $12^{\text {th }}$ & 48,72 & 1,07 & 4,15 & 24,15 & 14,63 & 0,86 & 43,12 & 2,39 & $-0,44$ & 94,62 & $-0,43$ & 5,58 & 65,83 & 0,94 & 0,66 \\
\hline $13^{\text {th }}$ & 47,15 & 1,04 & 3,45 & 26,47 & 12,90 & 3,20 & 46,84 & 1,86 & $-0,60$ & 93,73 & 0,03 & 4,54 & 67,22 & 1,05 & 3,93 \\
\hline $14^{\text {th }}$ & 56,46 & 1,19 & 5,68 & 29,06 & 12,73 & 4,66 & 45,82 & 2,49 & $-0,06$ & 91,76 & $-0,48$ & 4,40 & 66,78 & 0,69 & 2,75 \\
\hline $15^{\text {th }}$ & 44,68 & 1,12 & 3,33 & 31,22 & 14,28 & 6,58 & 45,89 & 2,89 & 1,26 & 92,65 & $-0,51$ & 3,54 & 68,61 & 0,55 & 2,03 \\
\hline $16^{\text {th }}$ & 59,18 & 3,95 & 6,04 & 29,30 & 22,87 & 0,54 & 42,99 & 6,32 & $-1,49$ & 91,22 & $-0,47$ & 4,47 & 70,93 & 0,01 & $-6,69$ \\
\hline $17^{\text {th }}$ & 53,87 & 1,81 & 6,19 & 28,00 & 15,65 & 4,09 & 42,75 & 6,36 & $-1,37$ & 87,98 & 0,07 & 4,13 & 70,88 & 0,03 & $-6,70$ \\
\hline $18^{\text {th }}$ & 48,45 & 1,34 & 4,89 & 29,98 & 14,64 & 5,44 & 43,50 & 5,31 & $-1,19$ & 89,59 & $-0,44$ & 4,25 & 69,17 & 0,24 & $-6,41$ \\
\hline $19^{\text {th }}$ & 53,70 & 2,35 & 6,12 & 31,04 & 14,41 & 6,29 & 43,09 & 5,04 & $-0,89$ & 90,36 & $-0,47$ & 4,26 & 75,30 & $-0,41$ & $-5,15$ \\
\hline $20^{\text {th }}$ & 44,92 & 3,32 & 2,69 & 21,79 & 16,78 & 1,71 & 41,61 & 2,32 & $-0,72$ & 90,82 & $-0,90$ & 1,88 & 70,73 & $-0,61$ & $-4,95$ \\
\hline $21^{\text {st }}$ & 48,04 & 2,57 & 3,04 & 25,12 & 14,34 & 1,48 & 44,97 & 4,20 & 0,13 & 90,74 & $-0,4$ & 2,76 & 65,52 & $-0,30$ & $-3,61$ \\
\hline $22^{\text {nd }}$ & 43,05 & 2,19 & 4,84 & 27,65 & 14,12 & 2,60 & 45,13 & 3,82 & $-0,12$ & 89,91 & $-0,48$ & 2,75 & 72,43 & $-0,74$ & $-4,81$ \\
\hline $23^{\text {rd }}$ & 48,13 & 2,48 & 2,80 & 34,76 & 10,51 & 0,62 & 43,95 & 5,48 & $-0,88$ & 90,18 & $-0,47$ & 2,49 & 67,55 & $-0,48$ & $-4,95$ \\
\hline $24^{\text {th }}$ & 47,08 & 3,95 & 7,72 & 28,17 & 18,89 & 2,20 & 43,50 & 3,60 & $-2,09$ & 93,71 & $-1,01$ & 2,95 & 77,83 & 0,25 & 3,53 \\
\hline $25^{\text {th }}$ & 50,19 & 3,11 & 5,31 & 39,44 & 14,01 & 8,09 & 44,69 & 3,33 & $-1,54$ & 92,34 & $-0,97$ & 3,41 & 76,37 & $-0,07$ & 2,13 \\
\hline $26^{\text {th }}$ & 52,33 & 3,60 & 7,82 & 33,17 & 15,75 & 7,12 & 44,48 & 3,89 & $-1,51$ & 93,01 & $-1,01$ & 3,65 & 71,85 & $-0,12$ & 3,30 \\
\hline $27^{\text {th }}$ & 44,72 & 1,93 & 4,17 & 35,54 & 15,64 & 8,61 & 43,90 & 2,92 & $-0,92$ & 92,32 & $-0,97$ & 3,88 & 75,89 & 0,37 & 3,95 \\
\hline $28^{\text {th }}$ & 51,97 & 2,74 & 8,24 & 37,21 & 21,26 & 2,78 & 42,12 & 2,55 & $-3,41$ & 90,43 & $-0,40$ & 5,16 & 79,00 & $-0,49$ & $-0,52$ \\
\hline $29^{\text {th }}$ & 49,98 & 2,55 & 7,22 & 38,29 & 15,09 & 8,86 & 42,24 & 2,69 & $-2,28$ & 87,69 & 0,60 & 5,26 & 84,41 & $-0,75$ & $-1,70$ \\
\hline $30^{\text {th }}$ & 48,61 & 1,64 & 5,26 & 38,42 & 14,93 & 9,98 & 42,42 & 2,74 & $-1,81$ & 88,51 & $-0,72$ & 3,84 & 79,90 & $-0,68$ & $-0,94$ \\
\hline $31^{\text {st }}$ & 50,75 & 2,24 & 5,32 & 38,26 & 14,45 & 10,03 & 42,53 & 2,17 & $-1,82$ & 86,05 & 1,29 & 5,31 & 80,40 & $-0,78$ & $-0,36$ \\
\hline $32^{\text {vd }}$ & 48,05 & 4,21 & 3,35 & 34,13 & 11,38 & 0,64 & 44,06 & 1,08 & $-0,84$ & 87,96 & $-1,52$ & 6,19 & 72,66 & 0,37 & $-1,61$ \\
\hline $33^{\text {rd }}$ & 46,76 & 2,41 & 2,88 & 35,14 & 11,63 & 2,12 & 43,88 & 1,05 & $-0,11$ & 86,68 & $-1,02$ & 7,63 & 73,39 & 0,13 & $-1,34$ \\
\hline $34^{\text {th }}$ & 41,65 & 1,15 & 5,52 & 33,53 & 11,77 & 1,16 & 43,07 & 1,68 & $-0,48$ & 86,84 & $-1,91$ & 6,54 & 79,27 & $-0,09$ & $-3,14$ \\
\hline $35^{\text {th }}$ & 50,54 & 2,04 & 7,77 & 33,20 & 10,84 & 2,55 & 38,61 & 1,47 & $-0,41$ & 84,39 & $-1,91$ & 6,71 & 84,55 & $-0,11$ & 2,74 \\
\hline $36^{\text {th }}$ & 99 & 2,73 & 3,23 & 16 & 53 & 3,14 & 36,96 & 1,19 & $-0,46$ & 87,11 & 87 & 6,44 & 24 & $-1,27$ & 9,00 \\
\hline
\end{tabular}

In $\mathrm{L}^{*}, \mathrm{a}^{*}$ and $\mathrm{b}^{*}$ values, measured in fish fillets are observed fluctuations. While the $\mathrm{L}^{*}$ (luminosity) value was 46,66 at the beginning, it decreased to 36,96 at the end of $36^{\text {th }}$ hours as well as the luminosity wasdecrease. While the $\mathrm{a}^{*}$ (redness) value in the gills was 19.91 at the beginning of the experiment it decreased up to 10.53 at the end of the experiment; due to this reason, the red color of gills decreased in parallel with spoilage. At the beginning and end of the experiment, measured of, the positive $a^{*}$ and negative $b^{*}$ values shows a red and blue colors respectively.Inprogress of time, the darkness of these colors increased later on decreased.

Five panelists were selected for sensory analysis of the gray mullet and sensory analysis was performed every hour.Panelists were asked to give score $0-10$ points in terms of color, smell and general appearance of the fish (1-2: not consumable 3-4: bad, 5-6: consumable, 7-8: good, 9-10: excellent).

Thepanelistswerestatedthatthefishwas in a goodquality at thebeginning, it startedtodry at $3^{\text {th }}$ hours, theeye hole occurto form at $4^{\text {th }}$ hours, it beganstink at $5^{\text {th }}$ hoursandthegillsturnedintofrompinkcolortoredcolor at $7^{\text {th }}$ hours. They was reported that the gray mullet cannot be marketed anymore and lost entire quality at $12^{\text {th }}$ hour of sensory analysis.Results of the sensory analysis are indicated in Table 3.3.

Table3.3. Thereresults of sensoryanalysis

\begin{tabular}{|l|l|l|l|}
\hline Hour & Color & Odour & General appearance \\
\hline Begining of experiment & $9,10 \pm 0,10^{\mathrm{a}}$ & $9,30 \pm 0,12^{\mathrm{a}}$ & $9,00 \pm 0,00^{\mathrm{a}}$ \\
\hline $\mathbf{1}^{\text {st }}$ & $9,10 \pm 0,10^{\mathrm{a}}$ & $8,90 \pm 0,10^{\mathrm{ab}}$ & $8,90 \pm 0,10^{\mathrm{a}}$ \\
\hline $\mathbf{2}^{\text {nd }}$ & $8,50 \pm 0,16^{\mathrm{ab}}$ & $8,40 \pm 0,10^{\mathrm{bc}}$ & $8,20 \pm 0,12^{\mathrm{b}}$ \\
\hline $\mathbf{3}^{\text {rd }}$ & $7,90 \pm 0,10^{\mathrm{bc}}$ & $7,90 \pm 0,10^{\mathrm{cd}}$ & $8,00 \pm 0,00^{\mathrm{b}}$ \\
\hline $\mathbf{4}^{\text {th }}$ & $7,80 \pm 0,12^{\mathrm{bc}}$ & $7,60 \pm 0,10^{\mathrm{d}}$ & $7,70 \pm 0,12^{\mathrm{bc}}$ \\
\hline $\mathbf{5}^{\text {th }}$ & $7,30 \pm 0,12^{\text {cd }}$ & $6,90 \pm 0,10^{\mathrm{e}}$ & $7,20 \pm 0,12^{\text {cd }}$ \\
\hline $\mathbf{6}^{\text {th }}$ & $6,90 \pm 0,10^{\mathrm{de}}$ & $6,20 \pm 0,12^{\mathrm{f}}$ & $6,80 \pm 0,12^{\mathrm{de}}$ \\
\hline $\mathbf{7}^{\text {th }}$ & $6,30 \pm 0,12^{\mathrm{e}}$ & $6,00 \pm 0,00^{\mathrm{f}}$ & $6,50 \pm 0,22^{\mathrm{e}}$ \\
\hline $\mathbf{8}^{\text {th }}$ & $5,50 \pm 0,22^{\mathrm{f}}$ & $5,20 \pm 0,12^{\mathrm{g}}$ & $5,90 \pm 0,10^{\mathrm{f}}$ \\
\hline $\mathbf{9}^{\text {th }}$ & $5,30 \pm 0,12^{\mathrm{f}}$ & $4,30 \pm 0,20^{\mathrm{h}}$ & $4,90 \pm 0,10^{\mathrm{g}}$ \\
\hline $\mathbf{1 0}^{\text {th }}$ & $4,40 \pm 0,19^{\mathrm{g}}$ & $3,30 \pm 0,12^{1}$ & $4,00 \pm 0,00^{\mathrm{h}}$ \\
\hline $\mathbf{1 1}^{\text {th }}$ & $3,70 \pm 0,20^{\mathrm{g}}$ & $2,00 \pm 0,16^{\mathrm{j}}$ & $2,90 \pm 0,19^{1}$ \\
\hline $\mathbf{1 2}^{\text {th }}$ & $1,40 \pm 0,24^{\mathrm{h}}$ & $1,00 \pm 0,00^{\mathrm{k}}$ & $1,10 \pm 0,10^{\mathrm{j}}$ \\
\hline
\end{tabular}

Values are shown as mean \pm standard error a,b,..e $\downarrow$ : Within the column, values with different letters are significantly different $(\mathrm{P}<0.05)$

Results of thesensory, chemicalandcoloranalysis of thegraymullet at thebeginningandend of theexperiment ( $36^{\text {th }}$ hours) areshowncomparatively in Table3.4.

Table3.4. Comparison of sensory, chemicalandcoloranalysisresults

\begin{tabular}{|l|l|l|l|l|l|l|l|}
\hline Time & $\mathbf{L}^{*}$ & $\mathbf{a}^{*}$ & $\mathbf{b}^{*}$ & Color & Odour & General appearance & TVB-N mg/100 \\
\hline
\end{tabular}


Comparison Of Discolouration With Sensory And Chemical Qualities Of Gray Mullet...

\begin{tabular}{|l|l|l|l|l|l|l|l|}
\hline Begining of experiment & 46,66 & 2,04 & $-2,79$ & $9,10 \pm 0,10$ & $9,30 \pm 0,12$ & $9,00 \pm 0,00$ & $16,92 \pm 0,12$ \\
\hline 12 $^{\text {th }}$ & 46,26 & 2,12 & $-0,67$ & $1,40 \pm 0,24$ & $1,00 \pm 0,00$ & $1,10 \pm 0,10$ & $17,85 \pm 0,17$ \\
\hline 36 $^{\text {th }}$ & 36,96 & 1,19 & $-0,46$ & - & - & - & $35,93 \pm 0,16$ \\
\hline
\end{tabular}

The values corresponding to the $L^{*}, a^{*}$ and $b^{*}$ indices at the beginning are $(46,66),(2,04)$ and $(-2,79)$ respectively. Butthis values was reached $(46.26),(2.12)(-0.67)$ at the time when the fish was spoiled $\left(12^{\text {th }}\right.$ hour) in terms of sensory quality.

When the fish were decomposition in the sense of chemical quality (36 hours), $\mathrm{L}^{*}, \mathrm{a}^{*}$ and $\mathrm{b}^{*}$ values was reached $(36,26),(1,19)$ and $(-0,46)$ values respectively. Images at the beginning, $12^{\text {th }}$ hour (moment when it was breakdown in terms of sensory quality) and at $36^{\text {th }}$ hour (moment when it was breakdown in terms of chemical quality) of the experiment are shown in Figure 3.1, Figure 3.2 and Figure 3.3, respectively.

It is thought that comparison of color analysis with sensory and chemical analyses provide a numerical idea with regard to the shelf life and quality of the fish.

\section{DISCUSSIONS}

TVB-N analysis was performed in our study to determine chemical quality of fish meat. Classification of quality with TVB-N value in aquaculture varies with respect to the researchers. The results of this study were evaluated according to [6]

According to the study result, the TVB-N value of $16,92 \pm 0,12 \mathrm{mg} / 100 \mathrm{~g}$ at the beginning of the experiment was found as $35,93 \pm 0,16 \mathrm{mg} / 100 \mathrm{~g}$, exceeding the consumable limit value at the end of 36 hours.Nitrogen compounds in fish meat were rapidly disintegrated by the effect of temperature and subsequently increased the TVB-N value.

The increase in TVB-N value during storage was also detected in various investigators.In a study, Koralfumed to gray mullet, and evaluated the changes in the chemical quality under room and refrigerator conditions. According to determined TVB-N analysis results, fresh gray mullet samples was spoiled on $3^{\text {rd }}$ day at room temperature, while it was spoiled on 5th day in refrigerator. On the other hand, fumed gray mullet spoiled on $5^{\text {th }}$ day at room temperature and on $15^{\text {th }}$ day in refrigerator. In this study reported that the TVB-N values increase for each group [10].

Bahmani et al. [11]investigated that quality of mullet by keeping on the ice and in the refrigerator in their study.Theyhavebeen reported that determined TVB-N values increased in both groups during the 16-day storage period.

The color analysis showed that $\mathrm{L}^{*}, \mathrm{a}^{*}$ and $\mathrm{b}^{*}$ values were fluctuating in time. Increasingly negative (-) or positive (+) values means that they are darkened. Whenexamining the color change of gills, it was found that luminosity of $L^{*}$ value increased in time (from 25.63 to 32.16 ), at the beginning darkness of the $a^{*}$ (+ red) value decreased in time (from 19.91 to 10.53 ), as for $b^{*}$ value, fluctuations observed while this values increased.

In addition to the five color measurement locations (eye, gill, fish meat, ventral surface and skin), color analysis was also performed on the fish filet, according to this analysis, it was determined that, the value of $\mathrm{L}$ decreaseto 36.96 from 46.66 throughout the trial, was diminish brightness. As for the change in a* and $\mathrm{b} *$ values indicates, they were showed that the meat turns yellow and dark over time. Increase and decrease in $\mathrm{L}^{*}, \mathrm{a}^{*}$ and b* values depending on the storage period were detected by a number of researchers.

Erkan et al. [12]investigated the effect of Modified Atmosphere Packing on breaded salmon marinade stored at $4^{\circ} \mathrm{C}$. It was reported that the $\mathrm{L}^{*}$ value in control group decreased with time, namely the meat became darker.

Çaklı et al. [13]carried out color analysis on fishes during storage, and reported that the fishes became less luminous, redder and more yellow. In a study performed on anchovy, Küçükgülmez[14]found L* value of control group as 45.89 on the first day and 38.91 on the last day after 18-day storage in refrigerator.

According to the sensory analysis, gray mullet spoiled at the end of $12^{\text {th }}$ hour. Köse and Erdem[15]investigated the quality change in anchovies stored at different temperatures (room temperature and refrigerator), and found that the shelf life of anchovy was 2 days in refrigerator and 1 day at room temperature.

\section{CONCLUSION}

There is no study which determines the "Color-Quality" relation in fishery.In this preliminary study, the limit and duration of sensory and chemical deterioration was determined and compared with changes in color throughout this period. The quality of the mullet can be determined in a short time thanks to color analysis which concluded in very short time and easy to applied. More comprehensive studies can be conducted with different fish species in different processing methods. By courtesy of color analysis and other quality analyzes, quality can be determined in a short time under all circumstances and contribution to the literature with new information by comparison of color analysis with other quality analyses. 


\section{REFERENCES}

[1]. O. Kılınçeker, E. Küçüköner, Determination of somephysical, chemicalandbiochemicalchanges on saltedpearlmullet (Chalcalburnustarichi). Yüzüncü Yll University, J. Agric. Sci., 13(1), 2003, 55-59.

[2]. Ş. Çaklı, D. Kışla, Microbialorigindeteriorationandpreventionmethods in aquaculture. E.U. Journal of Fisheries\&AquaticSciences.20, (1-2), 2003, $239-245$.

[3]. A. Üren, Üç boyutlu renk ölçme yöntemleri. Gıda, 24 (3), 1999, 193-200.

[4]. B. Ersoy, A. Özeren, Theeffects of defrostmethods on sensoryandcolourquality of Europeaneel (Anguilla anguilla). BiologicalSciencesResearch Journal,1(2), 2008, 09-11.

[5]. W. Ludorf, V. Meyer..Fischeundfischerzeugnisse. Verlag Paul Parey, Printed in Germany bei A. W. Hayn'sErben, 1973

[6]. C. Varlık, M. Uğur, N. Gökoğlu, H. Gün, Su ürünlerinde kalite kontrol ilke ve yöntemleri. (Gıda Teknolojisi Derneği Yayın No: 17, Ankara, 174 s, 1993).

[7]. J.A. Abbott,Qualitymeasurement of fruitsandvegetables,PostharvestBiologyTechnology, 15, 1999, $207-225$.

[8]. M. Ünlüsayın, R.Erdilal,Texture Profile Evaluation fortheFreshSeafood. Ecological Life Sciences, 3(3), 2008, $424-435$.

[9]. Minitab, Inc. 2005. MINITAB statisticalsoftware, release 16for Windows. StateCollege, PA.

[10]. S. Koral, Investigatingthequalitychanges of rawandsmokedpacificmullet (Mugilso-iuyBasilewski, 1885) andbonito (SardasardaBloch, 1838) at ambientandrefrigeratedtemparatures, Karadeniz Technical University, Institute of ScienceandTechnology, MA, 2006.

[11]. Z.A. Bahmani, M. Rezai, S.V. Hosseini, J.M. Regenstein, K. Böhme, A. Alishahi, F. Yadollahi, Chilledstorage of golden graymullet (Lizaaurata), LWT FoodScienceandTechnology 44, 2011, 1894-1900.

[12]. N. Erkan, S. Metin, C. Varlık, T. Baygar, Ö. Özden, H. Gün, H. Kalafatoğlu, Theeffect of modifiedatmospherepackaging (MAP) on theshelf life of marinatedandbreadedrainbowtrout, TurkJournal of VeterinaryAnimalScience, 24, 2000, 585-591.

[13]. Ş. Çaklı, B. Kılınç, T. Dinçer, S. Tolasa, Shelf Life of New CultureSpecie (Diploduspuntazzo) in Refrigerator, Journal of MuscleFoods, 19, 2008, 315-332.

[14]. A. Küçükgülmez, Theeffects of theextractobtainedfromgiantredshrimp (Aristaeomorphafoliacea) shells on chemicalphysicalandsensorialproperties of refrigeratedanchovy (engraulisencrasicolus), University of Çukurova, TheInstitute of Natural andAppliedSciencesDepartment of Fishing andProcessingTechnology, Adana, 2011.

[15]. S. Köse, M.E. Erdem, An investigation of qualitychanges in anchovy(Engraulisencrasicolus, L. 1758) stored at differenttemperatures. TurkishJournal of VeterinaryandAnimalSciences, 28(3), 2004, 575-582. 